\title{
ENGLISH BORROWINGS IN COVID-19 PANDEMIC
}

\author{
Abdulloh \\ Sekolah Tinggi Bahasa Asing IEC Bekasi \\ abdullahgraha67@gmail.com \\ Sarsono \\ Sekolah Tinggi Bahasa Asing IEC Bekasi \\ sarsono999@gmail.com \\ Ikhwan Muslim \\ Sekolah Tinggi Bahasa Asing IEC Bekasi \\ ikhwanmuslim91@gmail.com
}

Abdulloh. Sarsono and Muslim, I (2020). English borrowings in COVID-19 pandemic. Journal of English Language and literature, 5(2), 17-30. doi: 10.37110/jell.v5i02.101

\begin{abstract}
This study describes English borrowing or loan words during COVID-19 pandemic frequently used by public and absorped by Indonesian. Some words mostly from medical and healthcare terms, but many of them are from daily, practical, social life terms. People don't realize that they use many unfamiliar words and phrases when they communicate in Indonesian. Those words are English borrowings. The aims of the study are ; (1) to investigate some English borrowing words or phrases, (2) to describe the borrowing process from English into Indonesian. The Qualitative Decriptive Analysis Method used in analysing English borrowings . Obtains 95 English words taken then classified into the process of borrowings. 56 words from 95 words or $58,95 \%$ already available in Kamus Besar Bahasa Indonesia (KBBI), 39 words or $41,05 \%$ is not listed in KBBI or signed with n.a or not available. In the borrowing process obtains 34 words or $35,7 \%$ as adoption , 45 words or $47,3 \%$ as adaptation, 14 words or $14,7 \%$ as translation, and the rest is 2 words or $2,1 \%$ as creation process. The result shows that English borrowings absorped by Indonesian through both adoption and adaptation are quite significant, total both is $83 \%$. It means that Indonesian is quite open language to foreign languages. This fact also shows that Indonesian is a dynamic, up to date, and modern language.
\end{abstract}

Key words: borrowing or loan words, adoption, adaptation, translation, and creation

\section{INTRODUCTION}

Since World Health Organisation (WHO) declared COVID-19 as global pandemic through out the countries around the world includes Indonesia, the use of medical terminology and other words or phrases of English frequently used and spoken by citizens nationally in our daily lives. Government through media and information steadily releases news, information, announcement, policy using some English borrowing words and phrases related with COVID-19 pandemic.
The words and phrases like pandemic, lockdown, social distancing, work from home (WFH), test from home (TFH), webinar , and many others are frequently used. Those words and phrases are not available in Indonesian yet. Those borrowings are viral everywhere.

Previously public are not really familiar with those words and phrases, then they just use them in Indonesian, and they don't realize that those words and phrases are borrowings from other language. Indonesian has many borrowing words from either regional or 
foreign languages. Javanese, Minangkabau, Sundanese, Madurese, Balinese, and Acehnese are group of regional languages contributed much Indonesian, Jones, Russel. (2008). While foreign languages influence Indonesian are English, Arabic, Dutch, Japanese, and Chinese, (Badan Bahasa Kemdikud). The main reason for borrowing is to provide a word from the source language variety when there is no suitable existing word in the target language, Chandra Sekhar Rao, V. (2018), in The Significance of the Words Borrowed Into English Language, or borrowings occur when there is no equivalent meaning in Indonesian.

The borrowing language has been existing for very long time since there was contact among nations through culture and language. Serial contributions of English borrowings in Indonesian have been made by Iwan Fauzi (2014) in " English Borrowings in Indonesian Newspaper. He investigated three foremost national newspapers for his article. He found 19,494 loan tokens of 3,538 loan types extracted from 3,671 text during his 3-monthinvestigation. In his paper Iwan investigates English borrowing words using very special computer software named GNU Aspell 0.50 Indonesian dictionary Package version 1.2-0. The software was run to elecit English borrowings, both established and nonestablished loans. "English Borrowing Words In Indonesian Daily Conversation" made by Ilinawati, Yokie P.D. (2018). This research investigates English borrowing words in Indonesian daily conversation. Ilinawati's reserach was quite unique because she investigates borrowing words when the students speak Indonesian in their English Club. She also reveals the process of English borrowing from the forms, the meaning, and the reason of English borrowing words in Indonesian. She emphasizes the discusssion of loan words or borrowing words into three classification, loan words, loan blend, loan shifts. The objects to be investigated are 20 students in English club activity.
Some other related works like, " A Study of English-Indonesian Borrowing Words in Daily Products" is made by Isna Kurnianingsih, Etik. (2010) in her thesis of bachelor degree of education in English Department. She mentioned some daily products borrowed from English such as the name of daily need products: soap and shampoo, cosmetics, and food. In Lexical Borrowing from the Arabic Language in an Islamic Course Conducted in English "Ikhlas Arshad, Nurul and Ahmad Shah,M.I. (2014) analyze the patterns and processes of borrowing that can occur in the retention of Islamic Arabic words. The research also reveals that the most common process of borrowing in the sample discourse is total importation, as loanwords make up the borrowed features. "The Loan Words in Indonesian" written by Devianty, Rina. (2016) also discusses some foreign language vocabularies in Indonesian. She also adds that foreign language loanword remains to be adjusted with the indonesian writing and pronunciation. " English Borrowing in Indonesian Entertainment Terminology" a thesis written by Alawi, Nabilah (2007). The important purpose of her research is to know the change of meaning that happened in the borrowing words from English into Indonesian in the entertaintment terminolgy.

The previous investigations show that English borrowings in Indonesian used in varied domains such as English borrowings in newspaper, daily conversation of English club, daily products, and entertainment terminology.The similarity of those studies is on investigating English borrowing words on their results, and the difference each of them has varied discussion and analysis at the end. There is no previous invesigation of English borrowings in Indonesian focus on healthcare, medical terms, some social life terms at one time together. And the English borrowings investigated in this research massively and widely used in society during outbreak of certain pandemic. This study investigates some English borrowings in Indonesian during 
COVID-19 pandemic from March to July 2020. It analyses the class word classification, borrowing process classification, and checking the availability of each borrowing in Kamus Besar Bahasa Indonesia (KBBI) and Senarai Padanan Asing Indonesia (SPAI), one of online services provided by Indonesia Ministry of Education (Kemdikbud). Whereas other studies focus only on class word classification, borrowing process, certain borrowing classification, and no KBBI availability analysis. The finding words in this research signed with KBBI and n.a. KBBI means the English borrowings already available in Indonesian through adaptation, translation, and creation. While n.a. means not available yet in $\mathrm{KBBI}$, these words fully adopted without any changes.

This study has many shortcomings due to the limitation of the writer in all aspects such as limitation of background knowledge, theoritical and practical knowledge, and linguistical analysis. In the next future, there should be more complete study and further research of English borrowings in phonological, morphological, and semantical prespectives.

\section{Borrowing Words or Loan Words,}

In Indonesian, borrowing words or loan words are recognized as "kata serapan, kata pungutan or kata pinjam". It means that a word that comes from foreign languages, and is already integrated into a language that is accepted by its speakers in common. A loanword (also loan word or loan-word) is a word adopted from one language (the donor language) and incorporated into another language without translation. This is in contrast to cognates, which are words in two or more languages that are similar because they share an etymological origin, and calques, which involve translation. Merriam webster dictionary defines a loan word as a word taken from another language and at least partly naturalized.

Loan word is also a technical term for the incorporation of an item from language into another (Mesthrie \& Leap (2000) in Fauzi, Iwan (2014). In Loan word, Poplack et. al. (1998) specifically indicates that lexical borrowing involves the incorporation of individual second language (L2) words (or compounds funtioning as single words) in to the first language (L1) discourse, the host or recipient language, phonologically and morphologically adapted to conform with patterns of that language, and occupying a sentence slot indicated by its syntaxt. Those all definitions conclude that borrowing is the synonym of loanword. It is an absorption word, phrase, or others from one language to another language through phonological, morphological changes. Borrowing is attempted to get the equivalent meaning of its original because of the scarcity of model.

\section{Culture and Intimate Loan Words}

Indonesian has many borrowing words from other languages. Imran prosiding in Elizabeth (2018) adds that through loan words from other languages, Indonesian has many synonyms that can be expressed in high presission.Indonesian loan word consists of a culture loan words and intimate loan words. Culture loan words came to Indonesian from Sanskrit, Arabic, Portuguese, and English. These languages came to Indonesia through education, science and technology, religion and commerce. While intimate loan word comes from Chinese and Dutch. They came to Indonesia through war, colonialism, and immigration, Devianty,Rina (2016). Fredrich W. Field in Tatu,Siti Rubiah,et.al (2017) derives loan words into three kinds as follows; firstly: loan word, it is fully absorption from other word or language such as: hamburger ---$\rightarrow$ from hamburger. Secondly loan blend, it is only half absorption for example : klub -- $\rightarrow$ from club. And the last one loan shift, it is shifting absorption for example superman -- $\rightarrow$ from superman.

\section{Model and Donor Language}

The languange change and development naturally happen in our lives. It is because of interaction or contact among the speakers, Siti Rohbiah, Tatu et al, (2017). It is not only a contact among the languages, but also among the culture and as a result they influence each other. The contact of language cause direct and direct effect of the language. A language that receive influence from other language called Model, while a language that influnces other 
language called Donor. Then the process of donor influence model called borrowings, Mackey, Wiliam, in Siti Rohbiah, Tatu et.al (2017).

Adoption, Adaptation, Translation, and

\section{Creation}

Indonesian vocabularies enriched by some absorption process, loan or borrowing words from many foreign languages such as English, German, Dutch, French, and Arabic.Those loan words came to Indonesian through four processes, they are: Adoption, Adaptation, Translation, and Creation, Fauzi, Iwan (2014).

- Adoption occurs when the language user takes form and meaning of the foreign language tottaly sucha as supermarket, plaza, mall, hamburger, fried chicken, pizza etc.

- Adaptation occurs when the user of language take only the meaning of the original language, while the spelling and the writing system adapted with Indonesian spelling such as pluralisasi from pluralization, kualitas from quality, kuantitas from quantity etc.

- Translation way occurs when the users take concept contains of foreign langauage words then the translation in Indonesian. The examples are tumpang tindih from overlap, percepatan from acceleration, proyek rintisan from pilot project, and uji coba from try out.

- Creation way occurs when the user of language only take the basical concept of its oriiginal language then try to look for the equivalent words in Indonesian. It looks like translation way . but the diffrence is try not to force the similarity on the translation. Two word , three - word vocabulary of original language can be created into only one-word of Indonesian vocabulary or vice versa. The examples ; suku cadang from spare parts, berhasil guna from effective etc.

\section{Why borrowing words ?}

Some facts influence the absorption mentioned by Field, Fredrick W (1984) in Linguistic Borrowing in Bilingual Context, they are;

Economical Principal. We choose the loanwords due to the economical consideration in delivering the concept. There is no equivalent meaning or words in Indonesian.If there is an Indonesian word, it is long word as well it is not economical.

- The Scarcity Of Original Word or Model. There are some Indonesian words rarely used even for the active and productive speakers. Only linguists and experts are familiar with the original words.

- Equivalent Meaning Needs. Stylistic consideration empower speakers to look for synonyms and equivalent meaning of word, and it is just for esthetical variation.

- Prestige of Using Foreign Language. The more fluently speaker speaks foreign language, the more prestige they are in their social status sepecially the foregn language which has high civilization.

- The Poor Ability of the Speaker Language More elite social people have more foreign language vocabularies than Indonesian vocabularies.

Sometimes using English words is effective, efficient, economical, that's why people prefer English to their own. The most dominant factors for youngster for prestige and life style consideration. They don't realize where they are now. They live in Indonesia, they speak Indonesian among the community.

Moeliono in Abdul Chaer (2019) agrees with the same factors influence the absorption as mentioned above such as economical consideration, scarcy original form or word, equivalent word needs, prestige, poor in using Indonsian.

\section{Change of Meaning (Semantical Change or}

\section{Semantical Shift)}

The changing meaning of words occur due to the additional and reductional meaning in the quantity or quality of words. There are six kinds of semantical changes as follows :

- Generaization (boardening or widening meaning)

- Specification (narrowing meaning)

- Amelioration (raisng or elevation meaning)

- Peyoration (declining meaning)

- Synthesthesia (changing meaning)

- Association (similarity meaning)

Semantical change classified into three categories by Chaer, A ; Widening, Narrowing, Total Change, Chaer, A. (2019). 
- Widening meaning occurs if the meaning of the present word (model) or the new meaning is wider or broader than the previous meaning of the word. It means the meaning of the loan word undergoes additional, widening, and developing from the donor.

- Narrowing meaning occurs if the new meaning of model is more specific than the donor. It means the meaning of the loan word undergoes specification or narrowing meaning from the donor.

- Total change meaning occurs the new meaning of the model doesn't have meaning of the model.

Semantical change is also other loanwords discussion. It dicsusses the change of word meaning. This study doesn't focus on it, it focuses on lexical discussion.

\section{METHOD}

Qualitative Decriptive Analysis Method used by writer to investigate English loan words or borrowing words in Indonesian. Qualitative Descriptive analysis is a method of research by collecting, structuring, analysing, and interpreting the data, Nasir, Moh. (2019). There are two kinds of source of data, primary and secondary data. Primary data taken from online articles, online news, TV, You tube, posters, instagram, government announcement, government decree, government public policy, banners, and certain websites related with and focus on COVID 19 Pandemy, while online Journals, online dictionary, google translate, wikipedia, social media, websites, and books are taken as secondary data.

\section{Procedure}

Writer watches some related youtubes, watches and listens the news from TV, browse official website of World Health Organisation, official sites of government in charge with COVID-19 (Satgas COVID 19), notes some selected loan words from the primary data, reads the related books, Journals, and article, collects and selects primary data of English borrowing words or phrases related with COVID-19, then analyzes and interprets them. English words then defined into the class word classification wheather they are noun, verb, adjective, and etc., then writer consults the meaning in Indonesian using online Kamus Besar Bahasa Indonesia (KBBI) and some standard English dictionaries. At the end writer provides classification of the loan words into category of process of loan or borrowing words such as; adoption, adaptation, translation, and creation.

After listing all English words complete, then the data listed put into table to ease writer analyzing the loan words, see Table 1 . Table 1 is taken from the long list preceded. By using the table it is more concise and practical. After completing words list into table 1 , the writer procedes the table into significant summary that become focus or finding and discussion of the research Then data in table 1 summarized into table 2. Table 2 shows the complete discussion of the findings.

\section{FINDINGS AND DISCUSSION}

\section{Findings}

The data of English borrowing words listed in certain notes, then the words will be directly defined the meaning by using English Indonesian Dictionary. Then the writer uses KBBI to detect whether English loan words already have been as official and standar Indonesian vocabulary or not. When it is already available in KBBI then given the meaning of the new borrowing or loan words. The list of words then classified into class word or part of speech. The next analysing is based on the four process of Adoption, Adaptation, Translation and Creation. Some abreviation made to shorten the data anlayzed., such as : BI for Bahasa Indonesia, lw for loanword, na for not available yet Bahasa indonesia, KBBI for Kamus Besar Bahasa Indonesia.

There are 95 English borrowings words obtained from the primary data such as article, news, poster, youtube, official social media , public discussion, daily conversation, and some official sites during COVID-19 pandemic. The loanwords mostly taken from you tube channel benpinter. Then the writer only puts some examples for the findings into some classification as follows:

\section{Adoption Process \\ (with category available and not available in KBBI yet (na))}


1. viral : adjective ; virus

BI (lw): viral ; berkenaan dengan virus, bersifat menyebar luas dan cepat seperti virus.(KBBI) >>> adoption

2. zoonosis: noun; zoonosis penyakit pd binatang yg dapat ditularkan kepada manusia seperti penyakit pes yg merupakan penyakit tikus secara langsung atau melalui serangga

BI (lw) : zoonosis ; Penyakit pada binatang yang dapat ditularkan kepada manusia seperti penyakit pes yang merupakan penyakit tikus) secara langsung atau melalui serangga . (KBBI) >>> adoption

3. droplets : noun ; titis kecil, percikan ; butiran ludah-kedokteran)

BI (lw ): not available (na) $\gg>>$ adoption

4. hand sanitizer : noun ; pembersih tangan

$\mathrm{BI}(\mathrm{lw})$ : na ; hand sanitizer >>>> adoption

: synonym ; hand antiseptic ; handrub

5. sanitizer: noun ; pembersih

BI (lw) : na ; sanitizer >>> adoption

\section{Adaptation, available in KBBI}

1. asymtomatic : (adjective ) ; tanpa gejala

BI: (lw 1) : asimtomatik ; tidak menyebabkan atau menunjukkan ada gejala penyakit

(KBBI) $\quad>>>$

adaptation

2. contact: (noun); kontak

BI (lw) : kontak; hubungan satu dengan yang lain $(\mathrm{KBBI})$ >>> adaptation

avoid contact with : verb; menghindari

kontak dengan

3. elimination: noun : eliminasi , pembersihan, penyisihan

BI (lw) : eliminasi : pengeluaran (seperti racun dari tubuh); penghilangan, penyingkiran;

(KBBI) $\gg>>>$ adaptation pengasingan, penyisihan.

\section{Translation,}

(with category available and not available in KBBI yet (na))

\section{1. scanner : noun ; pemindai}

$\mathrm{BI}(\mathrm{lw})$ : pemindai ; lat untuk memeriksa atau mengamati data yang direkam; alat untukmemindai sesuatu (misalnya tubuh manusia), perangkat keras untuk mengopi gambar dan teks dalam bentuk digital (KBBI) >>> translation
2. suspect corona : noun ; tersangka korona : orang yang diduga terinfeksi COVID-19, baik dari gejala yang ditunjukkan maupun adanya riwayat kontak dekat dengan pasien positif corona.

$\mathrm{BI}(\mathrm{lw})$ : na ; diduga korona (KBBI) >>>> translation

3. self-isolate : verb ; mengasingkan diri , mengisolasi diri $\gg>>>$ translation

BI (lw 22): na :

\section{Creation, available in KBBI}

1. on line : noun; on line

BI (lw): dalam jaringan (Daring) : terhubung melalui jejaring komputer, internet, dan sebagainya $(\mathrm{KBBI})$ > > > creation.

2. off line: noun : off line

$\mathrm{BI}(\mathrm{lw})$ : luar jaringan : luring: terputus dari jejaring komputer (KBBI) > >> creation.

The following words below are already available in Bahasa Indonesia and had process of absorption from medical and healthcare terminology and officially used by government for COVID-19 terminology.

- ODP : Orang Dalam Pemantauan: people in monitoring

- PDP : Pasien Dengan Pengawasan: patient with supervision

- OTG : Orang Tanpa Gejala : people without symptom

- APD : Alat Pelindung Diri : personal protective equipment or clothes - PSBB: Pembatasan Sosial Bersekala Besar: large-scale social restrictions.

Besides the list obove, we are also familiar with some pictures, posters, banners, sign, otdoor boards, outdoor billboard every where related with the health protocol during COVID -19 Pandemic. WHO officially publishes poster about healthcare education to the public. The writer will not investigates those all because they are not the core of this paper and there must be follow up research deal with pictures, symbols and borrowing languages during COVID-19 pandemic.

\section{DISCUSSION}

The following table is summary of English borrowing words listed above with some information to complete the discussion of the 
paper. It contains 6 columns, column 1.Englsih word (donor) : English vocabulary taken from primary data mostly taken from youtube channel benpinter and other sources, column 2. Class word of donors, column 3. Meaning is taken directly from online English Indonesian Dictionary, column 4.Indonesian words , model (KBBI), English words that already absorped into Indonesian, it is the English borrowing words, and already listed in online Kamus Besar Bahasa Indonesia, with other sign n.a means not available yet in KBBI, column 5. Process of Borrowing written as adoption, adaptation, translation, and creation. Column 6. Note Words are not listed yet in KBBI or Indonesian.

Table 1: English Borrowing Words and Phrases

\begin{tabular}{|c|c|c|c|c|c|c|}
\hline No. & $\begin{array}{l}\text { Engish Word } \\
\text { (Donor) } \\
\text { (1) }\end{array}$ & $\begin{array}{c}\text { Class } \\
\text { Word } \\
(2)\end{array}$ & $\begin{array}{c}\text { Meaning } \\
\text { (3) }\end{array}$ & $\begin{array}{c}\text { Indonesian } \\
\text { word, Model } \\
(\mathrm{KBBI}) \\
(4)\end{array}$ & $\begin{array}{c}\text { Process of } \\
\text { borrowing } \\
\text { (5) }\end{array}$ & $\begin{array}{l}\text { Note } \\
(6)\end{array}$ \\
\hline 1. & asymptomatic & adjective & tanpa gejala & asimtomatik & adaptation & \\
\hline 2. & symptom & noun & gejala & simtom & adaptation & \\
\hline 3. & symptomatic & adjective & $\begin{array}{l}\text { yang menunjukan } \\
\text { gejala }\end{array}$ & simtomatik & adaptation & \\
\hline 4. & Contact & noun & Kontak & kontak & adaptation & \\
\hline 5. & droplets & noun & $\begin{array}{l}\text { titis kecil, percikan: } \\
\text { butiran ludah }\end{array}$ & n.a & adoption & droplets \\
\hline 6. & contact tracing & $\begin{array}{l}\text { noun, } \\
\text { noun } \\
\text { phrase }\end{array}$ & pelacakan kontak & n.a & $\begin{array}{l}\text { adoption } \\
\text { translation }\end{array}$ & $\begin{array}{l}\text { contact } \\
\text { tracing } \\
\text { pelacakan } \\
\text { kontak }\end{array}$ \\
\hline 7. & tracing & noun & pelacakan & n.a & translation & pelacakan \\
\hline 8. & Diagnose & verb & mendiagnosis & diagnosa & adaptation & \\
\hline 9. & diagnoses & noun & $\begin{array}{l}\text { diagnosis } \\
\text { diagnosis }\end{array}$ & diagnosis & adaptation & \\
\hline 10. & infection & noun & Infeksi, penularan & Infeksi & adaptation & \\
\hline 11. & infected & $\begin{array}{l}\text { adjective } \\
\text { or Verb } \\
\text { past part }\end{array}$ & infeksi penularan & Infeksi & adaptation & \\
\hline 12. & infect & verb & $\begin{array}{l}\text { menulari, } \\
\text { menginfeksi }\end{array}$ & n.a & translation & menulari \\
\hline 13. & infectious & adjective & yg menular & infeksius & adaptation & \\
\hline 14. & hand sanitizer & $\begin{array}{l}\text { noun, } \\
\text { noun } \\
\text { phrase }\end{array}$ & pembersih tangan & n.a & adoption & $\begin{array}{l}\text { hand } \\
\text { sanitizer }\end{array}$ \\
\hline 15. & sanitizer & noun & pembersih & n.a & adoption & sanitizer \\
\hline 16. & sanitation & noun & kebersihan & sanitasi & adaptation & \\
\hline 17. & virus & noun & virus & virus & adoption & \\
\hline 18. & Viral & adjective & virus & viral & adoption & \\
\hline 19. & anti viral medecine & $\begin{array}{l}\text { noun } \\
\text { noun }\end{array}$ & obat antivirus & n.a & translation & $\begin{array}{l}\text { obat } \\
\text { antivirus }\end{array}$ \\
\hline
\end{tabular}


Abdulloh, Sarsono and Ikhwan Muslim

English borrowings in COVID-19 pandemic

\begin{tabular}{|c|c|c|c|c|c|c|}
\hline & & phrase & & & & \\
\hline 20. & $\begin{array}{l}\text { antiviral / } \\
\text { antivirus }\end{array}$ & noun & antivirus & antivirus & adoption & \\
\hline 21. & isolate & verb & $\begin{array}{l}\text { Mengisolasikan,meng } \\
\text { asingkan }\end{array}$ & isolir & adaptation & \\
\hline 22. & self-isolate & $\begin{array}{l}\text { verb } \\
\text { verb } \\
\text { phrase }\end{array}$ & mengasingkan diri & n.a & translation & $\begin{array}{l}\text { isolasi } \\
\text { mandiri }\end{array}$ \\
\hline 23. & Isolation & noun & isolasi, pengasingan & isolasi & adaptation & \\
\hline 24 & novel coronavirus & $\begin{array}{l}\text { noun, } \\
\text { noun } \\
\text { phrase }\end{array}$ & virus korona baru & n.a & adoption & $\begin{array}{l}\text { novel } \\
\text { coronaviru } \\
\text { S } \\
\end{array}$ \\
\hline 25. & coronavirus & Noun & virus korona & virus korona & adaptation & \\
\hline 26. & $\begin{array}{l}\text { Coronavirus Disease } \\
\text { 2019: COVID -19 }\end{array}$ & $\begin{array}{l}\text { noun, } \\
\text { noun } \\
\text { phrase }\end{array}$ & $\begin{array}{l}\text { penyakit virus korona } \\
2019\end{array}$ & n.a & translation & \\
\hline 27. & $\begin{array}{l}\text { SARS-CoV-2 } \\
\text { Severe Acute } \\
\text { Respitory Syndrome }\end{array}$ & $\begin{array}{l}\text { noun, } \\
\text { noun } \\
\text { phrase }\end{array}$ & $\begin{array}{l}\text { sindrom pernafasan } \\
\text { akut/berat }\end{array}$ & n.a & adoption & $\begin{array}{l}\text { SARS-CoV- } \\
2\end{array}$ \\
\hline 28. & CoV : coronavirus & $\begin{array}{l}\text { noun, } \\
\text { noun } \\
\text { phrase }\end{array}$ & virus korona & virus korona & adaptation & \\
\hline 29. & carrier & noun & pembawa & n.a & adoption & Carrier \\
\hline 30 . & community spread & $\begin{array}{l}\text { noun, } \\
\text { noun } \\
\text { phrase }\end{array}$ & $\begin{array}{lr}\text { penularan } & \text { penyakit } \\
\text { secara } & \text { langsung } \\
\text { dalam } & \text { suatu } \\
\text { komunitas } & \\
\end{array}$ & n.a & adoption & $\begin{array}{l}\text { community } \\
\text { spread }\end{array}$ \\
\hline 31. & community & noun & masyarakat & komunitas & adaptation & \\
\hline 32. & $\begin{array}{l}\text { community } \\
\text { transmission }\end{array}$ & $\begin{array}{l}\text { noun, } \\
\text { noun } \\
\text { phrase }\end{array}$ & $\begin{array}{lr}\text { penularan } & \text { penyakit } \\
\text { secara } & \text { langsung } \\
\text { dalam } & \text { suatu } \\
\text { komunitas } & \end{array}$ & n.a & adoption & $\begin{array}{l}\text { community } \\
\text { transmissio } \\
n\end{array}$ \\
\hline 33. & transmission & noun & penularan & transmisi : & adaptation & \\
\hline 34. & Zoonosis & noun & $\begin{array}{l}\text { penyakit pd } \\
\text { binatang yg } \\
\text { dapat ditularkan } \\
\text { kepada manusia } \\
\text { seperti penyakit pes } \\
\text { yg merupakan } \\
\text { penyakit tikus secara } \\
\text { langsung atau melalui } \\
\text { serangga }\end{array}$ & zoonosi & adoption & \\
\hline 35. & detect & verb & $\begin{array}{l}\text { mendeteksi, } \\
\text { menemukan }\end{array}$ & deteksi & adaptation & \\
\hline 36. & Detection & noun & deteksi & deteksi & adaptation & \\
\hline 37. & screening & noun & $\begin{array}{l}\text { uji tapis, } \\
\text { penyaringan } \\
\text { (rangkaian }\end{array}$ & n.a & adoption & screening \\
\hline
\end{tabular}




\begin{tabular}{|c|c|c|c|c|c|c|}
\hline & & & $\begin{array}{lr}\text { pemeriksaan } & \text { yg } \\
\text { bertujuan } & \text { utk } \\
\text { mengetahui } & \text { risiko } \\
\text { suatu penyakit } & \end{array}$ & & & \\
\hline 38. & disinfect & verb & $\begin{array}{l}\text { membasmi } \\
\text { kuman/hama } \\
\text {, mendis } \\
\text { infeksi }\end{array}$ & $\begin{array}{l}\text { mendisinfek } \\
\text { si }\end{array}$ & adaptation & \\
\hline 39 & Disinfectant & $\begin{array}{l}\text { noun or } \\
\text { adjective }\end{array}$ & $\begin{array}{l}\text { obat pembasmi } \\
\text { kuman, yg } \\
\text { membasmi kuman/ } \\
\text { mendis } \\
\text { infeksi }\end{array}$ & disinfektan & adaptation & \\
\hline 40. & eliminate & verb & $\begin{array}{l}\text { menghilangkan, } \\
\text { mengeliminasi }\end{array}$ & $\begin{array}{l}\text { mengelimin } \\
\text { asi }\end{array}$ & adaptation & \\
\hline 41. & elimintaed & $\begin{array}{l}\text { adjective } \\
\text { or verb } \\
\text { past part. }\end{array}$ & tereliminasi & tereliminasi & adaptation & \\
\hline 42. & elimination & noun & $\begin{array}{l}\text { eliminasi, } \\
\text { pembersihan, } \\
\text { penyisihan }\end{array}$ & eliminasi & adaptation & \\
\hline 43. & maintain a distance & $\begin{array}{l}\text { verb } \\
\text { verb } \\
\text { phrase }\end{array}$ & menjaga jarak & n.a & translation & Jaga jarak \\
\hline 44. & social distancing & $\begin{array}{l}\text { noun, } \\
\text { noun } \\
\text { phrase }\end{array}$ & $\begin{array}{l}\text { pembatasan jarak } \\
\text { sosial }\end{array}$ & n.a & adoption & $\begin{array}{l}\text { social } \\
\text { distancing }\end{array}$ \\
\hline 45 & social & adjective & $\begin{array}{l}\text { sosial;kemasyarakata } \\
\text { n }\end{array}$ & sosial & adaptation & \\
\hline 46. & physical distancing & $\begin{array}{l}\text { noun, } \\
\text { noun } \\
\text { phrase }\end{array}$ & $\begin{array}{l}\text { pembatasan jarak } \\
\text { fisik }\end{array}$ & n.a & adoption & $\begin{array}{l}\text { physical } \\
\text { distancing }\end{array}$ \\
\hline 47. & physic & noun & fisik & fisik & adaptation & \\
\hline 48. & physical & adjective & $\begin{array}{l}\text { secara } \\
\text { fisik, jasmaniah, } \\
\text { badaniah }\end{array}$ & fisik & adaptation & \\
\hline 49. & stay home & verb & tinggal di rumah & n.a & translation & $\begin{array}{l}\text { tinggal di } \\
\text { rumah }\end{array}$ \\
\hline 50. & $\begin{array}{l}\text { Work From Home: } \\
\text { (WFH) }\end{array}$ & $\begin{array}{l}\text { verb, } \\
\text { verb } \\
\text { phrase }\end{array}$ & bekerja dari rumah & n.a & adoption & Wfh \\
\hline 50. & $\begin{array}{l}\text { Work From Home } \\
\text { (WFH) }\end{array}$ & $\begin{array}{l}\text { verb, } \\
\text { verb } \\
\text { phrase }\end{array}$ & bekerja dari rumah & n.a & translation & $\begin{array}{l}\text { bekerja dari } \\
\text { rumah }\end{array}$ \\
\hline 51. & lock down & $\begin{array}{l}\text { noun, } \\
\text { noun } \\
\text { phrase }\end{array}$ & karantina wilayah & n.a & adoption & lock down \\
\hline 52. & quarantine & noun & karantina & karantina & adaptation & \\
\hline 53. & self-quarantine & $\begin{array}{l}\text { noun, } \\
\text { noun } \\
\text { phrase }\end{array}$ & karantina mandiri & $\begin{array}{l}\text { karantina } \\
\text { mandiri }\end{array}$ & translation & \\
\hline 54. & Incubation & noun & inkubasi & inkubasi & adaptation & \\
\hline 55. & period & noun & titik, masa, waktu & periode & adaptation & \\
\hline
\end{tabular}


Abdulloh, Sarsono and Ikhwan Muslim

English borrowings in COVID-19 pandemic

\begin{tabular}{|c|c|c|c|c|c|c|}
\hline 56. & incubation period & $\begin{array}{l}\text { noun, } \\
\text { noun } \\
\text { phrase }\end{array}$ & masa inkubasi & $\begin{array}{l}\text { periode } \\
\text { inkubasi }\end{array}$ & adaptation & \\
\hline 57. & $\begin{array}{l}\text { PCR Test } \\
\text { Polymerase chain } \\
\text { reaction }\end{array}$ & $\begin{array}{l}\text { noun, } \\
\text { noun } \\
\text { phrase }\end{array}$ & $\begin{array}{l}\text { tes reaksi } \\
\text { berantai polimerase. }\end{array}$ & n.a. & adoption & $\begin{array}{l}\text { PCR Test } \\
\text { Tes PCR }\end{array}$ \\
\hline 58. & test negative & $\begin{array}{l}\text { verb, verb } \\
\text { phrase }\end{array}$ & $\begin{array}{l}\text { negative; } \quad \text { tidak } \\
\text { terinfeksi }\end{array}$ & tes negatif & adaptation & \\
\hline 59. & test positive & $\begin{array}{l}\text { verb, verb } \\
\text { phrase }\end{array}$ & positif terinfeksi & tes postif & adaptation & \\
\hline 60. & herd immunity & $\begin{array}{l}\text { noun, } \\
\text { noun } \\
\text { phrase }\end{array}$ & imunitas kelompok & n.a & adoption & $\begin{array}{l}\text { herd } \\
\text { immunity }\end{array}$ \\
\hline 61. & immunity & noun & kekebalan, imunitas & imunitas & adaptation & \\
\hline 62. & hygiene & noun & kebersihan & higienis & adaptation & \\
\hline 63. & epidemic & $\begin{array}{l}\text { noun and } \\
\text { adj: }\end{array}$ & wabah & epidemi & adaptation & \\
\hline 64. & pandemic & $\begin{array}{l}\text { noun and } \\
\text { adjective }\end{array}$ & wabah pandemic & pandemi & adaptation & \\
\hline 65. & outbreak & noun & $\begin{array}{l}\text { pecahnya wabah } \\
\text { perang bencana dsb } \\
\text { atau kejadian luar } \\
\text { biasa KLB }\end{array}$ & outbreak & adoption & outbreak \\
\hline 66. & Pathogen & noun & $\begin{array}{l}\text { Patogen } \\
\text { parasit yang } \\
\text { mampu menimbulkan } \\
\text { penyakit pada } \\
\text { inangnya }\end{array}$ & patogen & adaptation & \\
\hline 67. & pneumonia & noun & $\begin{array}{l}\text { pneumonia penyakit } \\
\text { radang paru } \\
\text { paru }\end{array}$ & pneumonia & adoption & \\
\hline 68. & antibiotics & noun & antibiotik & antibiotik & adaptation & \\
\hline 69. & vaccine & noun & vaksin & vaksin & adaptation & \\
\hline 70. & Mask & noun & masker & masker: & adaptation & \\
\hline 71. & Contaminate & verb & $\begin{array}{l}\text { mengontaminasi, } \\
\text { mencemari }\end{array}$ & kontaminasi & adaptation & \\
\hline 72. & Thermal & adjective & $\begin{array}{l}\text { termal ; } \\
\text { panas }\end{array}$ & termal & adaptation & \\
\hline 73. & scanner & noun & pemindai & n.a & translation & pemindai \\
\hline 74. & thermal scanner & $\begin{array}{l}\text { noun, } \\
\text { Noun } \\
\text { phrase }\end{array}$ & $\begin{array}{l}\text { alat pemindai } \\
\text { termal(panas }\end{array}$ & n.a & translation & $\begin{array}{l}\text { pemindai } \\
\text { panas }\end{array}$ \\
\hline 75. & covidiot & noun & covidiot & n.a & adoption & Covidiot \\
\hline 76. & nasal & adjactive & $\begin{array}{l}\text { sengau, yang } \\
\text { berkenaan dengan } \\
\text { hidung }\end{array}$ & nasal & adoption & \\
\hline
\end{tabular}




\begin{tabular}{|c|c|c|c|c|c|c|}
\hline 77. & nasal congestion & $\begin{array}{l}\text { noun, } \\
\text { noun } \\
\text { phrase }\end{array}$ & hidung tersumbat & n.a & translation & $\begin{array}{l}\text { hidung } \\
\text { tersumbat }\end{array}$ \\
\hline 78. & face shield & $\begin{array}{l}\text { noun, } \\
\text { noun } \\
\text { phrase }\end{array}$ & pelindung wajah & n.a & adoption & face shield \\
\hline 79. & Protocol & noun & protokol & protokol & adaptation & \\
\hline 80. & suspect corona & $\begin{array}{l}\text { noun, } \\
\text { noun } \\
\text { phrase }\end{array}$ & $\begin{array}{l}\text { tersangka korona, } \\
\text { orang yang } \\
\text { diduga terinfeksi } \\
\text { COVID-19 }\end{array}$ & n.a & adoption & $\begin{array}{l}\text { suspect } \\
\text { corona }\end{array}$ \\
\hline 81. & reactive corona & $\begin{array}{l}\text { noun, } \\
\text { noun } \\
\text { phrase }\end{array}$ & reaktif korona & n.a & adoption & $\begin{array}{l}\text { reactive } \\
\text { corona }\end{array}$ \\
\hline 82. & reactive & adjective & reaktif & reaktif & adaptation & \\
\hline 83. & $\begin{array}{l}\text { CDC } \\
\text { Center for Disease } \\
\text { Control and } \\
\text { Prevention }\end{array}$ & $\begin{array}{l}\text { noun, } \\
\text { noun } \\
\text { phrase }\end{array}$ & $\begin{array}{l}\text { Pusat Pengendalian } \\
\text { dan } \\
\text { Pencegahan } \\
\text { Penyakit. }\end{array}$ & n.a. & translation & $\begin{array}{l}\text { Pusat } \\
\text { Pengendali } \\
\text { an dan } \\
\text { Pencegaha } \\
\text { n Penyakit }\end{array}$ \\
\hline 84. & swab test & $\begin{array}{l}\text { noun, } \\
\text { noun } \\
\text { phrase }\end{array}$ & tes usap & n.a & adoption & swab test \\
\hline 85. & specimen & noun & $\begin{array}{l}\text { spesimen contoh, } \\
\text { sampel }\end{array}$ & Spesimen & adaptation & \\
\hline 86. & rapid test & $\begin{array}{l}\text { noun, } \\
\text { noun } \\
\text { phrase }\end{array}$ & tes cepat & n.a & adoption & rapid test \\
\hline 87. & ventilator & noun & $\begin{array}{l}\text { ventilator, kipas } \\
\text { angin. }\end{array}$ & ventilator: & adoption & \\
\hline 88. & thermo gun & $\begin{array}{l}\text { noun, } \\
\text { noun } \\
\text { phrase }\end{array}$ & pistol termometer & n.a & adoption & thermo gun \\
\hline 89. & new normal & $\begin{array}{l}\text { noun, } \\
\text { noun } \\
\text { phrase }\end{array}$ & normal baru & n.a & adoption & new normal \\
\hline 89. & new normal & $\begin{array}{l}\text { noun, } \\
\text { noun } \\
\text { phrase }\end{array}$ & normal baru & n.a & translation & $\begin{array}{l}\text { Normal } \\
\text { baru }\end{array}$ \\
\hline 90. & $\begin{array}{l}\text { long distance } \\
\text { learning }\end{array}$ & $\begin{array}{l}\text { noun, } \\
\text { noun } \\
\text { phrase }\end{array}$ & $\begin{array}{l}\text { Pembelajaran Jarak } \\
\text { Jauh }\end{array}$ & n.a & translation & $\begin{array}{l}\text { PJJ : } \\
\text { Pembelajar } \\
\text { an Jarak } \\
\text { Jauh }\end{array}$ \\
\hline 91. & on line & adjective & on line & $\begin{array}{l}\text { daring, } \\
\text { dalam } \\
\text { jaringan }\end{array}$ & creation & \\
\hline 92. & off line & adjective & off line & $\begin{array}{l}\text { luring; di } \\
\text { luar } \\
\text { jaringan }\end{array}$ & creation & \\
\hline 93. & webinar & noun & webinar & n.a & adoption & Webinar \\
\hline 94. & zoom meeting & $\begin{array}{l}\text { noun, } \\
\text { noun } \\
\text { phrase }\end{array}$ & $\begin{array}{l}\text { pertemuan dengan } \\
\text { aplikasi zoom }\end{array}$ & n.a & adoption & \\
\hline 95. & $\begin{array}{l}\text { Test From Home } \\
\text { (TFH) }\end{array}$ & $\begin{array}{l}\text { noun, } \\
\text { noun }\end{array}$ & $\begin{array}{c}\text { tes dari } \\
\text { rumah }\end{array}$ & n.a & translation & \\
\hline
\end{tabular}


Obtained 95 English words from March 2020 to Juli 2020. Some words are already generally used in some terminolgy non COVID-19, most are medical and health care terminology. Recently we don't realize that those words are borrowing or loan words from other languages.

The classification Donor and Model from Table 1 taken from previous research by Siti Rohbiah ,Tatu. Et.al. (2017). The donor means the borrowing words from the original language , English words, Whereas model means a word in a language that receive donor, Indonesian word. The four process of borrowings category like adoption, adaptation, translation, and creation also investigated by Fauzi, Iwan (2014) in his journal. He also adds his investigation of loanwords by giving classification of class word. Yokie P.D, Ilinawati. (2018) analyzes loanwords in the forms and meaning in her journal. The three journals mentioned inspire writer to anlyze the loanwords into category of donor, model, word class, and meaning. Then writer adds item of KBBI availability in the table that makes different from the previous research.

Data from Table1 then summarized into Table 2. The table as follows ;

Table 2: Total number of borrowing words in concise

\begin{tabular}{|c|c|c|c|c|c|c|}
\hline $\begin{array}{l}\text { Total } \\
\text { English } \\
\text { Words } \\
\text { (Donor) }\end{array}$ & $\begin{array}{c}\text { Total KBBI } \\
\text { words } \\
\text { (Model) }\end{array}$ & $\begin{array}{l}\text { Total n.a } \\
\text { Words in } \\
\text { KBBI } \\
\text { (Model) }\end{array}$ & $\begin{array}{c}\text { Total } \\
\text { Adoption } \\
\text { Words }\end{array}$ & $\begin{array}{c}\text { Total } \\
\text { Adaptation } \\
\text { Words }\end{array}$ & $\begin{array}{c}\text { Total } \\
\text { Translation } \\
\text { Words }\end{array}$ & $\begin{array}{l}\text { Total } \\
\text { Creation } \\
\text { Words }\end{array}$ \\
\hline A & B & C & D & E & F & G \\
\hline 95 & 56 & 39 & 34 & 45 & 14 & 2 \\
\hline $100 \%$ & $58,95 \%$ & $41,05 \%$ & $35,89 \%$ & $47,37 \%$ & $14,74 \%$ & $2,11 \%$ \\
\hline $100 \%$ & $\begin{array}{r}\text { Total } \\
\text { Tot: } \\
1\end{array}$ & & & $\begin{array}{l}\text { Total Bor } \\
\text { Total D+E }\end{array}$ & $\begin{array}{l}\text { g Process } \\
\mathrm{G}=100 \%\end{array}$ & \\
\hline
\end{tabular}

From Table 2 , it can be analyzed that total donor is 95 , then the donor classified into model words that already included or available in KBBI and not available in KBBI yet signed with n.a. Total model 56 words from 95 words or $58,95 \%$ already available in KBBI, or it means 58,9\% English words already officially absorped into Indonesian. 39 English words from 95 or $41,05 \%$ are not available yet in KBBI, or it means around $41,05 \%$ of English words still no absorption yet.

The second disscussion of the research is borrowing process. From total donor 95 words, 34 words or $35,7 \%$ as adoption , 45 words or $47,3 \%$ as adaptation, 14 words or $14,7 \%$ as translation, and the rest is 2 words or $2,1 \%$ as creation process. Adaptation gets the first highest, 45 words or $47,3 \%$, it means English borrowing words already absorped by Indonesian then modified and adapted with Indonesian spelling and pronunciation. The examples of adaption are ; spesimen from specimen, reaktif from reactive, protokol from protocol, termal from thermal, vaksin from vaccine, pandemik from pandemic, epidemik from epidemic, etc. While the second highest is adoption 34 words or $35,7 \%$. In adoption process, Indonesian absorped English words totally without changes in spelling but sometimes the pronunciation influenced by Indonesian. Examples of Adoption are; thermo gun, face shield, swab test, rapid test, new normal, webinar, etc. Total both adaptation and adoption are quite big, it is 83 $\%$. It shows that English borrowings significantly influence Indonesian. The next 
one is translation 14 words or $14,7 \%$. Translation is used when there is no equivalent meaning of model words, Indonesian, for example: isolasi mandiri from self isolation, karantina mandiri from self quarantine, pemindai from scanner, jaga jarak from maintain distance, etc. The last one is creation 2 words or $2,1 \%$, for example daring (dalam jaringan) from on line, luring (luar jaringan) from off line.

The result of class word classification as follows; noun and noun phrase: 66 words or $69,5 \%$, noun/adjective: 3 words or $3,2 \%$, adjective and adjective/Verb past part: 13 words or $13,5 \%$, verb and verb phrase: 13 words or $13,5 \%$. The dominant word class is noun and noun phrase it is 66 words or $69,5 \%$.

The other examples of creation are already made by BPPB besides luring, daring are ; gawai from gadget, unduh from download, unggah from upload, etc. Soon, in the near future there will be either translation or creation from English borrowings related with COVID19 Pandemic in Indonesian that is provided by BPPB.More creation process will be made by Badan Pengembangan dan Pembinaan Bahasa (BPPB-Language Development Agency)

\section{CONCLUSION}

During COVID-19 pandemic, many unfamiliar words and phrases met every day in our life. Those words are English borrowings. They already inserted Indonesian and some of them already become Indonesian vocabularies

\section{REFERENCES}

Alawi, N.(2007). English Borrowings in Indonesian Entertainment Terminology. Thesis of S1 Degree, UIN Syarif Hidayatulloh, Jakarta.

Arshad, I., Nurul and Shah, A.M.I. (2014). Lexical Borrowing from the Arabic Language in an Islamic Course Conducted in English.Middle east Journal ofScientific Research 20 (Language for Communication and Learning): 110-117, 2014. ISSN 1990-9233.

Chaer, A. (2019). Linguitik Umum, Jakarta. Rineka Cipta. through process of adoption, adaptation, translation and creation. The prominent fact from the research is adaptation process, it gives significant contribution in the borrowing process compared with others. Now, we can easily detect those borrowings whether they already become Indonesian or not by using on line KBBI and on line SPAI. Those services provided by Ministry of Education and Culture through Badan Pengembangan dan Pembinaan Bahasa.

From the findings of English borrowings in Indonesian discussed above, it can be concluded that Indonesian easily receives foreign languages that can influence itself. This fact indicates that Indonesian or Bahasa Indonesia is open, up to date, modern, and dynamic language. Indonesian also tolerates to regional and foreign languages. The borrowing is not only from English but also from other foreign languages. That's why foreign borrowing language easily inserted and absorped by Indonesian.

Last but not the least the writer proposes wise suggestion to Indonesian speakers to be wise on using either foreign or regional language. There is wise saying that says" UTAMAKAN BAHASA INDONESIA , PELIHARA BAHASA DAERAH, KUASAI BAHASA ASING

(PRIORITIZE INDONESIAN, MAINTAIN REGIONAL LANGUAGE, MASTER FOREIGN LANGUAGE)

Devianty, R. (2016). Loan words in Indonesian. Vision vol.9, No.9 Januari Juni2016.ISSN:2086-4213.

Field, F. W. (1984), Linguistic Borrowing in Bilingual Context, Amsterdam:John Benjamin Publishing Company.

Fuazi, I.(2014). English Borrowings in Indonesian Newspapers, Journal on English as a Foreign Language, Volume 4, Number 1.p. 15

Ika, H., \& Elizabeth, A.N.R. (2018). Kata Serapan Dalam Bahasa Jepang. Kiryoku, Volume2, No.2. http://ejournal.undip.ac.id/index.php/kiryo $\mathrm{ku}$.

Jones, R.(2008). Loan-Words in Indonesian and Malay, compiled by 
Indonesianetymological project. Yayasan Pustaka Obor Indonesia, Jakarta.

Kurnianingsih, E.I. (2010). A Study of English -Indonesian Borrowing Words in DailyNeed Products. Research paper of bachelor degree of Education, English Department. FKIP -Universitas Muhammadiyah Surakarta.

Mackey, W. (1968). The Description of Bilingualism, in Joshua A Fishman (ed). Reading in Sociolgy of language, The Hauge : Mouton \& Company.

Mesthrie, R \& P Leap, W.L. (2000). Language Contact 1: Maintenance, Shift and Death. In Introducing Sociolinguistics (Ed.). Mesthrie, R., Swann, J., Deumert,A., andLeap,WL.Edinburgh:Edinburgh University Press.

Moeliono, AM., Rifai, M.A., Zabadi, F., \& Sugono,D.(2007). Pedoman Umum Pembentukan Istilah. Jakarta: Pusat Bahasa, Departemen Pendidikan Nasional

Nasir, M. (2019). Metode Penelitian, Jakarta: Ghalia, Indonesia.

Poplack, S. \& Sankoff, D. \& Miller,C.(1998). The Social Correlates and Linguistic Process of Lexical Borrowing and Assimilation. Linguistics,26.47-104

Rao, C.S. V. (2018). The Significance of the Words Borrowed Into English Language.Journal for Research Schoolars and Professionals of English Language Teaching. Suue6, Vol.2, 2018.http://jrspelt.com

Rohbiah, T.S.. et al. (2017). Perubahan Makna Kata Serapan Bahasa Arab dalamBahasa Inggris pada Istilah Ekonomi. Al-Turas, Mimbar Sejarah, Sastra, Budaya, dan Agama-Vol. XXIII No.2. Juli 2017.
Yokie P.D, Ilinawati. (2018). English Borrowings in Indonesian Daily Conversation. Journal of English Education Study (JEES). Journal on English. Volume 1 Issue 1.

https://www.merriamwebster.com/dictionary/loanwords https://www.cdc.gov/coronavirus/2019ncov/testing/serology-overview.html

https://www.youtube.com/watch?v=u06NIG9Sj $\mathrm{Gw}$

https://www.who.int/indonesia/news/novelcoronavirus https://covid19.go.id/ https://novelcoronavirus.onlinelibrary.wiley.com/ https://engliven.com/2020/03/05/kosa-katapenyakit/ https://www.who.int/indonesia http://who.int/covid-19 https://kbbi.kemdikbud.go.id/entri https://suaka.or.id/2020/03/30/indonesianhealth-protocol-for-covid-19/ https://kbbi.kemdikbud.go.id/ https://typoonline.com/kbbi/karantina https://spai.kemdikbud.go.id/v1/web/index.php https://gln.kemdikbud.go.id/glnsite/ https://labbineka.kemdikbud.go.id/ https://petabahasa.kemdikbud.go.id/ http://badanbahasa.kemdikbud.go.id/lamanbaha sa/content/keniscayaan-kamus-urban https://ojs.badanbahasa.kemdikbud.go.id/jurnal/ http://bahasasastra.kemdikbud.go.id/glosarium/ https://bipa.kemdikbud.go.id/portal https://dapobas.kemdikbud.go.id/ https://spai.kemdikbud.go.id 